http://nv.nltu.edu.ua

https://doi.org/10.15421/40290111

$@ \bowtie$ Correspondence author

Article received 13.02.2019 p.

O. L. Kratiuk

Article accepted 28.02.2019 p.

deneshi_ks@ukr.net

УДК 639.[1.04+1.053]:630*15(477.42)

о. Л. Кратюк

Житомирський наиіональний агроекологічний університет, м. Житомир, Украйна

\title{
ХАРАКТЕРИСТИКА ВОЛЬЄРІВ ЦЕНТРАЛЬНОГО ПОЛІССЯ
}

Досліджено стан вольєрного мисливського господарства на території Центрального Полісся. Перше вольєрне господарство в регіоні створив граф Йозеф Потоцький у 1900 р. на площі 5000 га. На 01.01.2019 р. у межах Центрального Полісся функціонує 16 вольєрів у мисливських господарствах різних форм власності. Упродовж 2007-2018 рр. ріст загальної площі вольєрів відбувається завдяки приватним мисливським господарствам. Якщо у 2007 р. площа вольєрів становила 417,2 га, то на початок 2019 р. - 602,2. Найбільшим у регіоні є вольєр СФГ "Земля Полісся" площею 228,0 га. Серед державних підприємств найбільші вольєри створено у ДП "Білокоровицьке ЛГ" (70,5 га) та ДП "Баранівське ЛМГ" (56,2 га). Ще чотири вольєри можна вважати (для Центрального Полісся) середніми, а саме: вольєр ТОВ "Клуб "КСК"" (61,0 га), ТОВ "УТМР" (58,8 га), ТОВ "МК "Хантер"" (40,0 га) та ТОВ "МРК "Рись"" (34,6 га). Останнім, у 2018 р., було створено вольєр у ТОВ "Престиж-О" площею 4,0 га для розведення Cervus nippon. Встановлено, що у відсотковому відношенні переважають вольєри площею до 5 га - 37 \% (n=6). Чверть загальної кількості становлять вольєри площею від 50 до 100 га $(n=4)$. За останні роки чисельність основного поголів'я ратичних тварин у вольєрах зростає стрибкоподібно. У 2018 р. чисельність тварин становила 178 особин 6 видів (Sus scrofa, Cervus elaphus, Cervus nippon, Dama dama, Capreolus capreolus, Ovis ammon), серед яких домінує Cervus elaphus.

Ключові слова: мисливське господарство; напіввільне утримання; Sus scrofa; Cervus elaphus; Cervus elaphus; Dama dama.

Вступ. Основним завданням мисливського господарства України є збереження, відтворення та раціональне використання мисливських ресурсів в умовах ускладнення процесів взаємодії у системі дикі тварини - навколишнє середовище - діяльність людини (Ароllonio et al., 2017). За таких обставин, однією з умов підвищення ефективності ведення мисливського господарства стало утримання тварин у напіввільних умовах (Khoietskyi, Novak \& Pokhaliuk, 2015). Більш досконалого контролю за популяцією дає можливість розведення тварин на відокремленій території, що веде до значного зростання чисельності та якості поголів'я. Особливо це актуально для невеликих мисливських господарств, яких переважна більшість, де через обмеженість площі та придатних до проживання стацій дуже важко сформувати здорову, повноцінну популяцію (Kratiuk, Guziy, Vlasiuk \& Bezditko, 2018).

Найперспективнішими видами для вольєрного розведення серед ратичних вважають свиню дику (Sus scrofa Linnaeus, 1758), оленя благородного (Cervus elaphus Linnaeus, 1758) та плямистого (Cervus nippon Temminck, 1838), а також лань (Dama dama Linnaeus, 1758) (Kaminetskyi et al., 2011), хоча нерідко в напіввільних умовах утримують і козулю європейську (Capreolus capreolus Linnaeus, 1758), муфлона європейського (Ovis ammon Linnaeus, 1758), зубра (Yevtushevskyi, 2009; Yevtushevskyi, 2012; Smagol \& Gavris, 2013).

Мета роботи - з'ясувати сучасний стан та розташування вольєрів у межах Центрального Полісся. Для до- сягнення поставленої мети передбачено виявити та проаналізувати наявні об'єкти напіввільного утримання ратичних тварин на території Центрального Полісся.

Матеріали та методи дослідження. Аналіз стану вольєрного мисливського господарства Центрального Полісся здійснено на основі матеріалів Державної служби статистики України, Державного агентства лісових ресурсів України, а також проектів організації і розвитку мисливського господарства користувачів мисливських угідь Житомирської області.

Результати дослідження та їх обговорення. Прообразом сучасного вольєрного мисливського господарства можна вважати мисливські парки великих магнатів XIX - початку XX ст.

Першим на території Центрального Полісся створив вольєр граф Йозеф Потоцький. Він у 1900 р. організував вольєрне господарство "Пилявин". Нині це територія Пилиповецького та Пищівського лісництв Державного підприємства "Новоград-Волинське досвідне лісомисливське господарство" Житомирського обласного управління лісового і мисливського господарства. Площа вольєра була досить великою навіть за сучасними мірками, за одними даними вона становила 5000 га, а за іншими - 3600 га. За короткий термін часу він зібрав велику колекцію ратичних Artiodactyla, яка у 1912 р. налічувала 304 особини, серед яких 8 зубрів (Bison bonasus Linnaeus, 1758) та 1 бізон (Bison bison Linnaeus, 1758) (Protsiv, 2018). До 1919 р. господарство разом із тваринами повністю знищили браконьєри (Smagol \& Gavris, 2013).

\section{Інформація про авторів:}

Кратюк Олександр Леонідович, канд. біол. наук, доцент, кафедра експлуатації лісових ресурсів. Email: deneshi_ks@ukr.net; https://orcid.org/0000-0002-2661-8074

Цитування за ДСтУ: Кратюк О. Л. Характеристика вольєрів Центрального Полісся. Науковий вісник НлтУ України. 2019, т. 29, № 1. C. 54-56.

Citation APA: Kratiuk, O. L. (2019). General Characteristics of Enclosures of Central Polissya. Scientific Bulletin of UNFU, 29(1), 54-56. https://doi.org/10.15421/40290111 
На початку XXI ст. у межах Центрального Полісся існувало 4 вольєри в таких господарствах: ДП "Баранівське ЛМГ", ДП "Радомишльське ЛМГ", СФГ "Земля Полісся" та МГ "В'юнки". У них утримували 46 особин Cervus nippon та 75 особин Sus scrofa (Kratiuk, 2018). 3 часом кількість вольєрів поступово починає зростати. Якщо у 2007 р. їх було 6, то на 01.01.2019 р. на території Центрального Полісся функціонує уже 16 вольєрів у мисливських господарствах різних форм власності (таблиця). За призначенням це переважно вольєри для тимчасового утримання та розведення мисливських тварин. Вольєри в межах Центрального Полісся розташовані рівномірно.

Таблиця. Характеристика вольєрів, розташованих у межах Центрального Полісся (на 01.01.2019 р.)

\begin{tabular}{|c|c|c|c|}
\hline $\begin{array}{l}\text { № } \\
3 / \text { ח }\end{array}$ & Користувач & Вид тварин & $\begin{array}{c}\text { Площа } \\
\text { вольєра, га }\end{array}$ \\
\hline 1 & ДП "Баранівське ЛМГ" & Cervus nippon & 56,2 \\
\hline 2 & $\begin{array}{c}\text { ДП "Білокоровицьке } \\
\text { ЛГ" }\end{array}$ & Sus scrofa & 70,5 \\
\hline \multirow{2}{*}{3} & \multirow{2}{*}{ ТОВ "УТМР" } & Cervus nippon & \multirow{2}{*}{58,8} \\
\hline & & Dama dama & \\
\hline 4 & \multirow{2}{*}{ ДП "Лугинське ЛГ" } & Capreolus capreolus & 1,5 \\
\hline 5 & & Sus scrofa & 1,5 \\
\hline 6 & $\begin{array}{c}\text { Житомирська ОО } \\
\text { УТМР } \\
\end{array}$ & Sus scrofa & 12,0 \\
\hline 7 & ТОВ "Престиж-О" & Cervus nippon & 4,0 \\
\hline 8 & СФГ "Земля Полісся" & Cervus elaphus & 228,0 \\
\hline \multirow{3}{*}{9} & \multirow{3}{*}{ ТОВ "МК "Хантер"" } & Cervus elaphus & \multirow{3}{*}{40,0} \\
\hline & & Dama dama & \\
\hline & & Ovis ammon & \\
\hline 10 & $\begin{array}{c}\text { Червоноармійська РО } \\
\text { УТМР }\end{array}$ & Sus scrofa & 12,0 \\
\hline \multirow{2}{*}{11} & \multirow{2}{*}{$\begin{array}{c}\text { ГО "Коростишівський } \\
\text { МК" }\end{array}$} & Sus scrofa & \multirow{2}{*}{15,0} \\
\hline & & Dama dama & \\
\hline 12 & ТОВ "Клуб "КСК" & Sus scrofa & 61,0 \\
\hline \multirow{2}{*}{13} & \multirow{2}{*}{ ТОВ "МРК "Рись"" } & Sus scrofa & \multirow{2}{*}{34,6} \\
\hline & & Capreolus capreolus & \\
\hline 14 & ДП "Овруцьке ЛГ" & Cervus elaphus & 1,6 \\
\hline 15 & ДП "Народицьке СЛГ" & Sus scrofa & 1,5 \\
\hline 16 & ГО "ЖОМК "Касадор"" & $?$ & 4,0 \\
\hline & 602,2 \\
\hline
\end{tabular}

Примітка: ? - встановити наявність тварин у вольєрі не вдалося

До цього переліку ми не включали вольєри, менші одного гектара, а також виставкові на території приватних садиб. Площі вольєрів різні - від 1-2 гектарів до сотень. Загальна площа вольєрів становить 602,2 га. Найбільшим можна вважати вольєр СФГ "Земля Полісся" площею 228,0 га. Серед державних підприємств найбільші вольєри розташовані у ДП "Білокоровицьке ЛГ" (70,5 га) та ДП "Баранівське ЛМГ" (56,2 га). Ще чотири вольєри можна вважати (для Центрального Полісся) середніми, а саме: вольєр ТОВ "Клуб "КСК" (61,0 га), ТОВ "УТМР" (58,8 га), ТОВ "МК "Хантер"" (40,0 га) та ТОВ "МРК "Рись"" (34,6 га). Останнім, у 2018 році, було створено вольєр у ТОВ "Престиж-О" площею 4,0 га для розведення Cervus nippon. (рис. 1).

У відсотковому відношенні переважають вольєри площею до 5 га - 37 \% $(n=6)$. Чверть загальної кількості становить вольєри площею від 50 до 100 га $(n=4)$.

Найстаршим із нині діючих вольєрів можна вважати вольєр на території Явненського лісництва ДП "Баранівське ЛМГ". Його створено згідно з рішенням технічної ради Баранівського лісгоспзагу від 16.03 .1985 року на площі 56,2 га для розведення Cervus nippon 3 подальшим відловом та розселенням у мисливські угіддя України.
За офіційною статистикою в умовах Центрального Полісся розташовано лише 9 вольєрів (рис. 2).

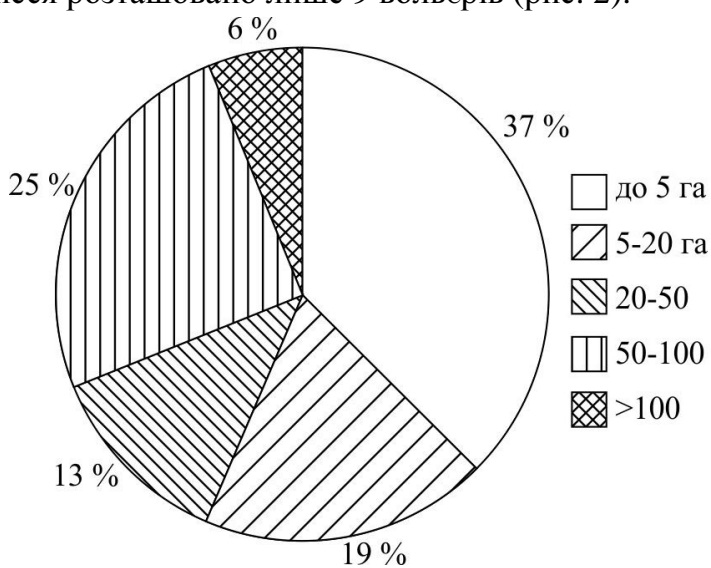

Рис. 1. Частка вольєрів за площею в умовах Центрального Полісся

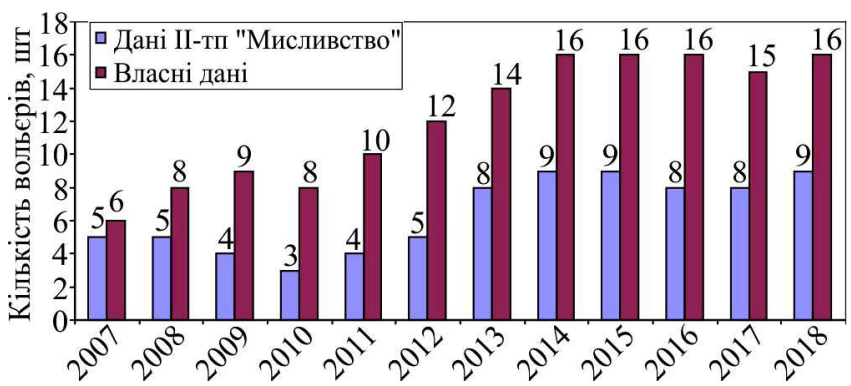

Рис. 2. Динаміка чисельності вольєрів у межах Центрального Полісся

На жаль, не всі вольєри потрапляють в офіційну статистику. Зазвичай такі користувачі створюють невеликі за площею вольєри для тимчасової перетримки тварин без подальшої селекційної роботи. Час існування таких вольєрів без значних капіталовкладень від 3-5 до 10 років. Така ситуація зумовлена, на нашу думку, кількома причинами, а саме: небажання афішувати свою діяльність, тимчасовий характер утримання тварин, зокрема хворих, а подекуди і звичайне недбальство відносно звітності. Так вольєр СФГ "Земля Полісся" та МГ "В'юнки" не потрапили до статистичної звітності у 2005-му та наступні роки. Лише у 2017 р. вольєр СФГ "Земля Полісся" з'явиться у статистичній звітності.

Упродовж останніх десяти років загальна площа вольєрів у межах Центрального Полісся поступово зростає (рис. 3). Упродовж 2007-2018 рр. зростання загальної площі вольєрів відбувається переважно завдяки приватним мисливським господарствам. Якщо у 2007 р. площа вольєрів становила 417,2 га, то на початок 2019 p. $-602,2$.

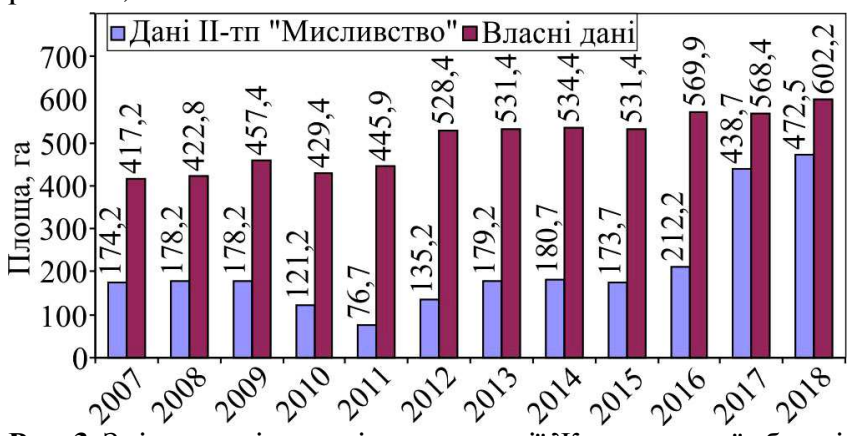

Рис. 3. Зміна площі вольєрів на території Житомирської області

За останні роки чисельність основного поголів'я ратичних тварин у вольєрах зростає стрибкоподібно 
(рис. 4). У 2018 р. чисельність тварин становила 178 особин 6 видів (Sus scrofa, Cervus elaphus, Cervus nippon, Dama dama, Capreolus capreolus, Ovis ammon), серед яких домінує Cervus elaphus.

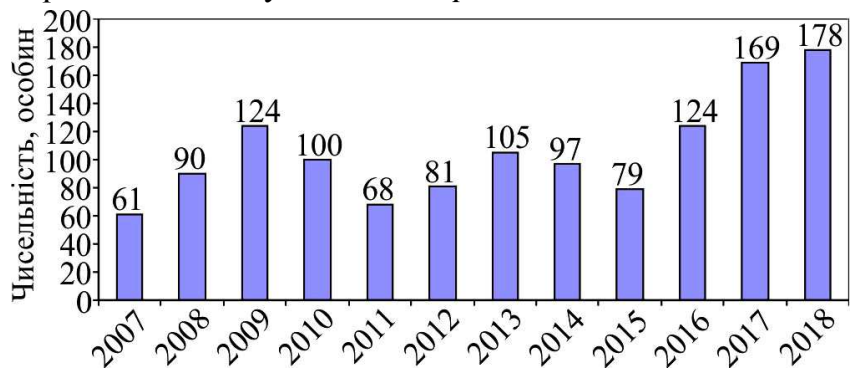

Рис. 4. Динаміка чисельності основного поголів'я ратичних тварин у вольсрах Центрального Полісся

Співвідношення видів у вольєрах наразі вирівнюється. Якщо у 2013 р. більше половини всього поголів'я $(52,4 \%)$ становила Sus scrofa, то за два роки - у 2016 р. - iї частка була вже 40,0\%, а на початку 2018 p. - лише 20,0\% (Kratiuk, 2018). Користувачі дедалі частіше надають перевагу Cervus elaphus, чисельність якого у вольєрах за останні роки зросла до 71 особини. Власники час від часу проводять випуски Cervus elaphus в угіддя. Так, навесні 2018 р. у ТОВ "МК "Хантер"" із вольєра випустили 26 особин Cervus elaphus, які успішно прижилися в угіддях. За свідченням єгерської служби, наразі відомо, що завдяки цьому в угіддях народилося 11 оленят.

Висновки та перспективи подальших досліджень. Отже, вольєрне мисливське господарство на території Центрального Полісся, володіючи сторічним досвідом та значним ресурсним потенціалом, має всі передумови до подальшого зростання, про що свідчить збільшення кількості вольєрів, їхні площі, кількості тварин та видо- вого складу. Наразі залишається нез'ясованим питання щодо впливу вольєрного утримання тварин на лісові насадження, особливо в невеликих за площею вольєрах, де в напіввільних умовах утримують Sus scrofa.

\section{Перелік використаних джерел}

Apollonio, M., Belkin, V. V, Borkowski, J., et al. (2017). Challenges and science-based implications for modern management and conservation of European ungulate populations. Mammal Research, 62, 209-217. https://doi.org/10.1007/s13364-017-0321-5

Kaminetskyi, V. K., Babich, O. H., \& Smahol, V. M. (2011). Ekolohichni ta hospodarski aspekty napivvilnoho rozvedennia dykykh kopytnykh (na prykladi spetsializovanykh pidpryiemstv Derzhavnoho upravlinnia spravamy Prezydenta Ukrainy). Kyiv: ZAT "Myronivska drukarnia", 154 p. [In Ukrainian].

Khoietskyi, P. B., Novak, A. A., \& Pokhaliuk, O. M. (2015). Wildlife management in european countries. Scientific Bulletin of UNFU, 25(3), 32-37. [In Ukrainian].

Kratiuk, O. L. (2018). Species Composition and Number Dynamics of Artiodactyla Ungulates in Enclosures in the Territory of Zhytomyr Region. Scientific Bulletin of UNFU, 28(3), 34-37. https://doi.org/10.15421/40280307

Kratiuk, O. L., Guziy, A. I., Vlasiuk, V. P., \& Bezditko, L. V. (2018). The Characteristic of Sanctuaries for Ungulates Artiodactyla on the Territory of Zhytomyr Region. Scientific Bulletin of UNFU, 28(2), 50-53. https://doi.org/10.15421/40280208

Protsiv, O. (2018). Volierne hospodarstvo hrafa Pototskoho. Lisovyi visnyk, 5-6(79-80), 38-39. [In Ukrainian].

Smagol, V. N., \& Gavris, G. G. (2013). The wisent Bison bonasus (Mammalia, Artiodactyla) in Ukraine: dynamics of population, area of distribution, habitat and limiting factors. Kyiv: Veles, 128 p. [In Russian].

Yevtushevskyi, M. N. (2009). Pliamystyi olen (Servus nippon hertulorum Swinhoe, 1864) v Ukraini ta za yii mezhamy. Kyiv: Eko-inform, 192 p. [In Ukrainian].

Yevtushevskyi, M. N. (2012). Myslyvski tvaryny Ukrainy na voli ta $v$ volierakh. Cherkasy: Vertykal, 376 p. [In Ukrainian].

\section{O. L. Kratiuk}

Zhytomyr National Agroecological University, Zhytomyr, Ukraine

\section{GENERAL CHARACTERISTICS OF ENCLOSURES OF CENTRAL POLISSYA}

The main types of semi-free maintenance in Central Polissya are considered to be ungulates. The characteristics of enclosures is based on the materials obtained from the State Statistics Service of Ukraine, the State Agency of Forest Resources of Ukraine, as well as projects for the organization and development of hunting farms of the users of hunting grounds in Zhytomyr Region. The first enclosure on the territory of Central Polissya was established by Joseph Pototsky in 1900 having started Pylyavyn enclosure farm. The area of the enclosure was quite large even according to modern standards and was about 5,000 ha. By 1919, the farm with animals had been completely destroyed by poachers. At the beginning of the 21 century, there were four enclosures within Central Polissya in such farms as Baranivske Hunting Forestry State Enterprise, Radomyshlske Hunting Forestry State Enterprise, Zemlya Polissya Peasant Farming, and Vyunky Hunting Farm. Forty six Cervus Nippon individuals and 75 Sus scrofa individuals were held there. There were 6 enclosures in 2007, and as of January 1, 2019 their number increased to 16. Concerning the land use, these are mainly enclosures for the temporary holding and breeding of game animals. The area of the enclosures is different ranging from one or two ha to hundreds of ha. Polissya Land Peasant Farming is the largest in the region with an area of 228.0 ha. Among the public enterprises, the largest enclosures are established in Bilokorovitsk State Forestry Enterprise (70.5 ha) and Baranivske Hunting Forestry State Enterprise (56.2 hectares). Another four enclosures can be considered medium scale for Central Polissya, namely KSK Club LLC (61.0 ha), USHF LLC (58.8 ha), Hunter HC LLC (40.0 ha), and Rys' HFC LLC (34.6 ha). In 2018, the last enclosure was established by Rys' HFC LLC at Prestige O LLC with an area of 4.0 ha for the cultivation of Cervus nippon. We have revealed that the enclosures with an area of up to $5 \mathrm{ha}-37 \%(n=6)$ prevail in percentage terms. A quarter of the total number consists of enclosures with an area ranging from 50 to 100 ha $(n=4)$. In the period from 2007 to 2019 , the area of enclosures increased from 417.2 га до 602.2 ha. In recent years, the amount of the main ungulate populations has shown a choppy increase in the enclosures. In 2018, the number of animals was 178 specimens of 6 species (Sus scrofa, Cervus elaphus, Cervus nippon, Dama dama, Capreolus capreolus, Ovis ammon), among which Cervus elaphus is dominant. Thus, having centuries of experience and considerable resource potential, enclosure hunting farms in the territory of Central Polissya have all the prerequisites for further growth, as evidenced by the increase in the number of enclosures, their area, the number of animals and species composition as well. Nowadays, the problem of the impact of holding animals in enclosures on forest stands is still to be solved, especially in the small open-air enclosures, where Sus scrofa is kept in semi-free conditions.

Keywords: hunting farm; semi-free maintenance; Sus scrofa; Cervus elaphus; Cervus elaphus; Dama dama. 